\title{
A Literature Review of Bhaskaralavana Churna for Ajeeranam in Indigenous Medicine
}

\author{
Janani Kandasamy $^{1^{*}}$, Yohalingam Desigan ${ }^{2}$, Nushrath Roshana Mansoor $^{3}$ \& Navaluxmy Nithiakumar ${ }^{4}$ \\ ${ }^{1-4}$ Unit of Siddha Medicine, University of Jaffna, Kaithady, Sri Lanka. \\ Email: tisasutha@gmail.com ${ }^{1 *}$,mzrddeshikan@gmail.com ${ }^{2}$,roshasiyad@gmail.com ${ }^{3}$,drnava18@gmail.com ${ }^{4}$
}

Copyright: (C) 2022 Janani Kandasamy et al. This is an open access article distributed under the terms of the Creative Commons Attribution License, which permits unrestricted use, distribution, and reproduction in any medium, provided the original author and source are credited.

The Sri Lankan Indigenous Medicine is a mixture of the Ayurveda, Siddha, Unani and Desheeya Chikitsa. Bhaskaralavanachurna is one of the internal medicine which is the herbo mineral preparation. Bhaskaralavanachurna is one of the most important drugs in Ayurvedha Government Hospitals in Sri Lanka. Therefore we selected this drug to literature review related it's ingredients for "Ajeeranam". This study was done at Unit of Siddha Medicine, University of Jaffna from October 2019 to January 2020. Data for the literature review were collected from relevant books, peer review journals and websites. It is consists scientific names; habitat; family; vernacular names; parts used; organoleptic characters; phytochemical; pharmacological actions for the ingredients of this drug. From this Churna has 18 ingredients, $14(77.7 \%)$ were medicinal plants and $04(22.2 \%)$ were minerals. Based on morphology 7 (50\%) plants were herbs. From these plants, $3(21.42 \%)$ of the species were found in Piperaceae family; 11 (78\%) were cultivated in Ceylon; 5 species $(35.75 \%)$ were used as fruits and $3(21.42 \%)$ were used as seeds. These plants contain pungent taste [10 $(45 \%)$ ] Salty [4 (18\%)], bitter [3 (14\%)], astringent [2 (9\%)], sweet [2 (9\%)] and sour [1 (5\%); hot potency [14 (78\%)], cold potency [3 (17\%)] and hot and cold [1 (5\%)]; pungent efficacy [16 (89\%)] and sweet [2 (11\%)]; pharmacological actions such as carminative [14 $(77.7 \%)$ ], stomachic [12 $(66.6 \%)$ ] stimulant [7 (38.8\%)] and astringent [3 (16.6\%)]. Phytochemicals such as volatile oil [8 (57.14\%)] and starch [4 (28\%)] were highly found in these medicinal plants. $100 \% \mathrm{Na}, 50 \% \mathrm{Mg}, 25 \% \mathrm{Ca}$, and $25 \% \mathrm{Cl}$ were found in these minerals. This literature review provides useful documented evidence related it's ingredients for Ajeeranam. There is need further laboratory study and toxicity study about this drug in future.

Keywords: Ajeeranam, Bhaskaralavanachurna, Herbomineral, Indigenous medicine.

\section{Introduction}

The Sri Lankan Indigenous Medicine is a mixture of the Ayurveda, Siddha, Unani and Desheeya Chikitsa [35]. Siddha medicine is an ancient system of medicine prevalent in South India [28]. The system is said to have emerged in antiquity from highly evolved consciousness of siddhars. They possessed super natural powers [34].

In Siddha medicine, the individual is microcosm of the universe. The human body consists of the five primordial elements and 7 physical constituents [28]. Vatham, pitham, kapham are three humors which are life constituents of the human body [23]. Disturbance and imbalance of humours leads to disease [34].

Treatment is aim at restoring balance to the mind and body system [28]. Siddhars can be classified the medicine type into three groups such as herbal products, mineral products and animal products [34]. There are 32 types of internal and 32 external medicines in siddha medicine [4].

Chooranam is one of the internal medicine which is the fine powder of drug. The raw drugs are purified separately then pounded separately, sieved mixed according to the given ratio. It is purified by pittavial process [4]. Bhaskaralavana churna is one of the internal medicine in the category of churnam which is the herbo mineral preparation which consist totally 18 ingredients, from this 14 were herbs and 04 were minerals [3].

Bhaskara Lavana churna is one of the most important drugs in Ayurvedha hospitals in Sri Lanka [5]. It was given for ajeeranam such as indigestion, gas flatulence, gastritis, loss of appetite, abdominal pain and constipation in the dose of $500 \mathrm{mg}-1500 \mathrm{mg}$, bd, before meal with hot water/Butter milk [3],[33]. Butter milk has high nutrient value and cooling properties (97.5 g moisture) [25]. 


\section{Methodology}

\subsection{Study design}

A literature review of Bhaskaralavana churna for ajeeranam in indigenous medicine.

\subsection{Place and study period}

Library at Unit of Siddha Medicine, University of Jaffna, Sri Lanka from October 2019 to January 2020.

\subsection{Research instrument}

Data entry form.

\subsection{Data collection}

Data for the literature review were collected from relevant books, peer review journals and websites with the help of data entry form which consists botanical names/scientific names, habitat, family, vernacular names, parts used, organoleptic characters, phytochemicals, and pharmacological actions for the ingredients of this drug.

\subsection{Statistical analysis}

Collected data were analyzed by simple statistical method with the help of MS Office 2010.

\section{Results and discussion}

\subsection{Taxonomic position of the medicinal plants}

Fourteen plants species belonging to 8 families which had been documented as remedies for ajeeranam were used for review. The taxonomic position of the individual plants is summarized in table 1. Plant taxonomy is the science that finds identifies, classifies, describes, and names of the plants [9].

\subsection{Family distribution of the medicinal plants}

A plant family is simply a collection of plants that share characteristics grouped together. Plants can be categorized by similar features such as overall appearance, seed groupings, flower, shape and to show their relationship to one another [35]. Families of the selected medicinal plants are shown in table 1.

Table 1. Taxanomic positions of the medicinal plants and family distribution of the medicinal plants

\begin{tabular}{|c|c|c|c|c|c|}
\hline $\begin{array}{c}\text { Botanical/ Scientific/ } \\
\text { Chemical names }\end{array}$ & \multicolumn{4}{|c|}{ Vernacular names } & $\begin{array}{c}\text { Family names/ } \\
\text { types of } \\
\text { minerals }\end{array}$ \\
\hline & Tamil name & English name & $\begin{array}{c}\text { Sinhala } \\
\text { name }\end{array}$ & Sanskrit name & \\
\hline Coriander sativum & Koththamalli & Coriander & Kottamalli & Ababika & Umbliferae \\
\hline Piper longum & Thipilli & Long pepper & Tipilli & Chapala & Piperaceae \\
\hline Piper lonfum & Thipilli moolam & Long pepper & Tipilli & Chapala & Piperaceae \\
\hline Nigella sativa & Karuncheeragam & Black cumin & Kaluduru & Bhashpika & Ranunculaceae \\
\hline
\end{tabular}


Asian Journal of Applied Science and Technology (AJAST)

Volume 6, Issue 1, Pages 01-10, January-March 2022

\begin{tabular}{|c|c|c|c|c|c|}
\hline Mesua ferrea & Sirunagampoo & Ceylon ironwood & Diyana & Naga & Guttiferae \\
\hline Abies webbiana & Thalisapathri & $\begin{array}{c}\text { Flaurtia } \\
\text { Himalayan silver }\end{array}$ & Talispatura & Talispathra & Coniferae \\
\hline Cinnamomum verum & Illavangam & Cinnamon & Kurundu & Balya & Lauraceae \\
\hline Cinnamomum tamala & Illavangam & Cinnamon & Kurundu & Balya & Lauraceae \\
\hline Garcinia cambogia & Korukkai & Brindle berry & Goraka & Madurammala & Guttiferae \\
\hline Elettaria cardamomum & Aealam & $\begin{array}{c}\text { Malabar } \\
\text { cardamomum }\end{array}$ & Ensal & Bahula & Zingiberaceae \\
\hline Cuminum cyminum & Seeragam & Cumin & Sudu-duru & Ajaji & Umbelliferae \\
\hline Piper nigrum & Milagu & Black pepper & Gammiris & Dharmavarttana & Piperaceae \\
\hline Punica granatum & Maathulai oodu & $\begin{array}{c}\text { Pomegranate fruit } \\
\text { shell }\end{array}$ & Delun & Dadima & Punicaceae \\
\hline Zingerber officinale & Sukku & Dry ginger & Inguru & Anupama & Zingerberaceae \\
\hline Sodium chloride & Kariyuppu & Table salt & Lunu & - & Kaarasaaram \\
\hline Black salt & Pitalavanam & Black salt & - & Krishna lavana & Kaarasaaram \\
\hline Asphalte & Kallupu & Asphalte & - & - & Kaarasaaram \\
\hline $\begin{array}{c}\text { Sodium chloride } \\
\text { impura }\end{array}$ & Induppu & Rock salt & & Saindhava & Kaarasaaram \\
\hline
\end{tabular}

From these medicinal plants, $21.4 \%$ of the species were found in Piperaceae. Umbelliferae, Lauraceae, Guttiferae and Zingiberaceae were $14.28 \%$ each other. Punicaceae, Coniferae, and Ranunculaceae were $7.14 \%$ each other.

\subsection{Parts of the medicinal plants used for Bhaskaralavana Churna}

Medicinal properties derived from plants may come from many different parts of a plant including leaves, roots, barks, seeds, fruits, and flowers.

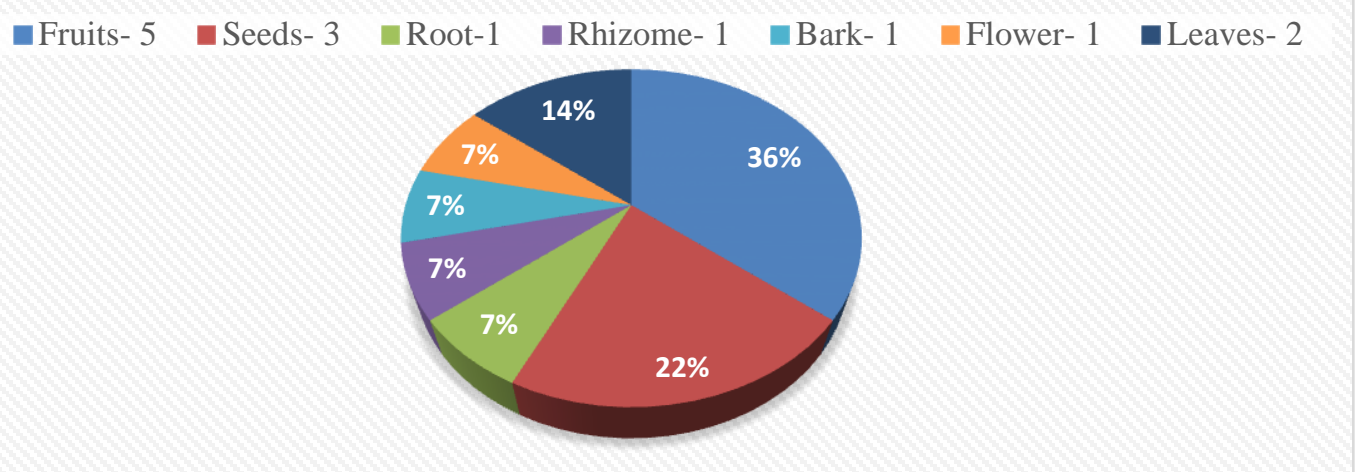

Fig.1. Parts of the medicinal plants used for Bhaskara lavana Churna

The different parts of these plants contain different active ingredients and organoleptic characters [11]. The review revealed that parts used for Bhaskaralavana Churna were fruits $35.71 \%$, seeds $21.42 \%$, leaves $14.28 \%$ and root, bark, dry rhizome and flowers were $7.14 \%$ each other [1],[8]. 


\subsection{Morphology of medicinal plants used for Bhaskaralavana Churna}

Plant morphology is the study of the physical form and external structure of plants. It is the study of the internal structure of plants. Plant morphology is useful in the visual identification of plants [10]. Based on the morphology of medicinal plants $50 \%$ plants were classified to be herbs, $35.71 \%$ trees and $14.28 \%$ shrub [1],[8].

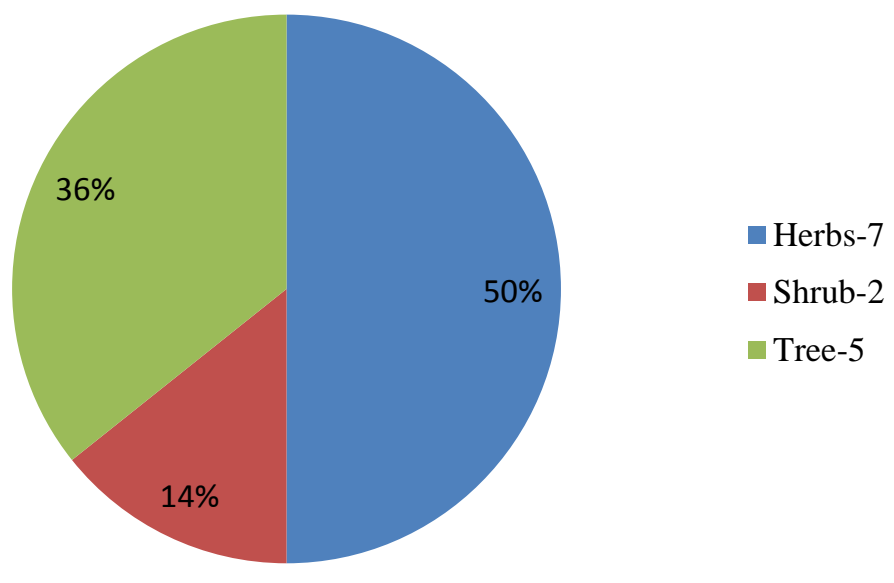

Fig.2. Morphology of medicinal plants

\subsection{Habitat of the medicinal plants used for Bhaskaralavana Churna}

The review indicates that $11(78.5 \%)$ plants are cultivated in Ceylon and $3(21.42 \%)$ plants are not cultivated in Ceylon. They are cultivated in foreign countries [2],[8].

\subsection{Siddha properties of medicinal plants and minerals of this Churna}

The drugs used by Siddha medicine are classified on the basis of five properties: taste, character, potency, efficacy and action [12]. Taste has got a significant place in Siddha medicine. Tongue experiences these tastes when a drug is administrated orally. Six tastes are sweet, salty, pungent, bitter and astringent. Potency is described as an active constituent of the drug which is responsible for the pharmacological activity of the medicinal herbs and other drugs. The drug has cold and hot potency. It is said to be the post absorptive taste which is an important aspect [13],[14].These plants contains siddha properties such as pungent taste $71.4 \%$, bitter $21.4 \%$ and sour, sweet and astringent were $7.1 \%$ each other. Minerals also have taste, potency and efficacy which are responsible for its pharmacological actions. These minerals were salty taste, hot potency and pungent efficacy. Table 2 shows its organoleptic characters of this medicinal plant and minerals of this drug [4].

Table 2. Ingredients with parts used and its organoleptic characters of this drug

\begin{tabular}{|c|c|c|c|c|c|}
\hline $\begin{array}{c}\text { Sl. } \\
\text { No. }\end{array}$ & Botanical names & Parts used & Tastes & Potency (Hot/cool) & $\begin{array}{c}\text { Efficacy } \\
\text { (vipakam) }\end{array}$ \\
\hline 1 & Coriander sativum & Seed & Pungent & Hot and cool & Pungent \\
\hline 2 & Piper longum & Fruit & Pungent & Hot & Pungent \\
\hline 3 & Piper longum & Root & Pungent & Hot & Pungent \\
\hline
\end{tabular}


Asian Journal of Applied Science and Technology (AJAST)

Volume 6, Issue 1, Pages 01-10, January-March 2022

\begin{tabular}{|c|c|c|c|c|c|}
\hline 4 & Nigella sativa & Seed & Bitter & Hot & Pungent \\
\hline 5 & Mesua ferrea & Flower & Bitter, Astringent & Cool & Pungent \\
\hline 6 & Abies webbiana & Leaves & Pungent & Hot & Pungent \\
\hline 7 & Cinnamomum verum & Bark & Pungent, sweet & Hot & Sweet \\
\hline 8 & Cinnamomum tamala & Leaves & Pungent & Hot & Pungent \\
\hline 9 & Garcinia cambogia & Fruit & Sour & Hot & Pungent \\
\hline 10 & Elettaria cardamomum & Seed & Pungent & Hot & Pungent \\
\hline 11 & Cuminum cyminum & Fruit & Pungent, sweet & Cool & Sweet \\
\hline 12 & Piper nigrum & Fruit & Pungent, Bitter & Hot & Pungent \\
\hline 13 & Punica granatum & Fruit shell & Astringent & Cool & Pungent \\
\hline 14 & Zingerber officinale & Dry rhizome & Pungent & Hot & Pungent \\
\hline 15 & Sodium chloride & - & Salty & Hot & Pungent \\
\hline 16 & Black salt & - & Salty & Hot & Pungent \\
\hline 17 & Asphalte & - & Salty & Hot & Pungent \\
\hline 18 & Sodium chloride impura & - & Salty & Hot & Pungent \\
\hline
\end{tabular}

\subsection{Pharmacological actions of the medicinal plants and minerals of this drug}

Action is the function of the drug. A drug has more than one action [13],[14]. The specific pharmacological actions of the medicinal plants and minerals which were utilized for the Bhaskaralavana are listed in Table 3. According to this table, carminative $66.6 \%$, stomachic $61.1 \%$, stimulant $38.8 \%$, digestive $5.5 \%$, astringent $16.6 \%$, refrigerant $5.5 \%$, laxative $5.5 \%$, diuretic $11.1 \%$, astringent $16.6 \%$ and alterative and tonic were $11.1 \%$ each other.

\subsection{Phytochemicals contents of this drug}

Phytochemicals are non-nutritive chemicals that have disease preventive properties which are active principle for function of the drug [15]. Common Phytochemicals of these plants such as volatile oil 57.1\%, essential oil 7.1\%, fixed oil $14.2 \%$, starch $28.5 \%$, resin $28.5 \%$, tannin $21.4 \%$, fatty oil $21.4 \%$ and gums $14.2 \%$. The minerals contain $\mathrm{Ca}, \mathrm{Mg}, \mathrm{Na}$ and $\mathrm{Cl}$ [2],[8]. Table 3 shows pharmacological actions and phytochemicals of ingredients of this drug.

Table 3. Pharmacological actions and phytochemicals of ingredients of this drug

\begin{tabular}{|c|c|c|c|}
\hline SI. No. & $\begin{array}{c}\text { Botanical name/ } \\
\text { Chemical name }\end{array}$ & Pharmacological actions & Phytochemicals \\
\hline 1 & Coriander sativum & $\begin{array}{c}\text { Carminative, stomachic, stimulant, } \\
\text { diuretic, aromatic refrigerant, tonic, } \\
\text { antibilious }\end{array}$ & $\begin{array}{c}\text { Coriandrol, volatile oil, malic acid, } \\
\text { mucilage, tannin, barboneol, } \\
\text { d-pinene }\end{array}$ \\
\hline 2 & Piper longum & Carminative, Stimulant, Diuretic, & $\begin{array}{c}\text { Piperine, volatile oil, starch, resin, } \\
\text { fatty oil and gum }\end{array}$ \\
\hline
\end{tabular}


Asian Journal of Applied Science and Technology (AJAST)

Volume 6, Issue 1, Pages 01-10, January-March 2022

\begin{tabular}{|c|c|c|c|}
\hline 3 & Piper longum & Stomachic, expectorant & $\begin{array}{l}\text { Piperine, volatile oil, starch, resin, } \\
\text { fatty oil and gum }\end{array}$ \\
\hline 4 & Nigella sativa & $\begin{array}{c}\text { Carminative, stomachic, diuretic, } \\
\text { emollient }\end{array}$ & $\begin{array}{l}\text { Volatile oil, essential oil, fixed oil, } \\
\text { Arabic acid, melanthin, carvone, } \\
\text { terpepene, nigelline, connigelline }\end{array}$ \\
\hline 5 & Mesua ferrea & Astringent, carminative & Essential oil, mesuol \\
\hline 6 & Abies webbiana & $\begin{array}{l}\text { Carminative, stomachic, } \\
\text { expectorant, tonic }\end{array}$ & Volatile oil, taxol, tannin, ephedrine \\
\hline 7 & Cinnamomum verum & Carminative, stimulant & $\begin{array}{c}\text { Sapponins, flavonoids, tannin, } \\
\text { phenolic acid }\end{array}$ \\
\hline 8 & Cinnamomum tamala & $\begin{array}{c}\text { Carminative, stomachic, stimulant, } \\
\text { diaphoretic }\end{array}$ & $\begin{array}{c}\text { Tannins, alkaloids, flavonoid, } \\
\text { terpenoids }\end{array}$ \\
\hline 9 & Garcinia cambogia & Carminative, digestive & $\begin{array}{l}\text { Hydroxycitric acid, polyphenols, } \\
\text { kaemperol }\end{array}$ \\
\hline 10 & $\begin{array}{c}\text { Elettaria } \\
\text { cardamomum }\end{array}$ & Carminative, stimulant, stomachic & $\begin{array}{l}\text { Volatile oil, fixed oil, cineole, } \\
\text { barneol, terpinyl acetate, barneol, } \\
\text { starch }\end{array}$ \\
\hline 11 & Cuminum cyminum & $\begin{array}{c}\text { Carminative, stomachic, astringent, } \\
\text { aromatic }\end{array}$ & $\begin{array}{c}\text { Fatty oil, cumin, cuminol, thymine, } \\
\text { cymene, resin, mucilage }\end{array}$ \\
\hline 12 & Piper nigrum & Carminative, stimulant, acrid & $\begin{array}{c}\text { Piperine, piperidine, volatile oil, } \\
\text { oleo resin }\end{array}$ \\
\hline 13 & Punica granatum & stomachic, astringent & $\begin{array}{l}\text { Gallo tannins, gallic acid, } \\
\text { punicalins, punicalagins }\end{array}$ \\
\hline 14 & Zingerber officinale & Stomachic, carminative, stimulant & $\begin{array}{l}\text { Zingerone, gingerol, volatile oil, } \\
\text { gingeberol, gingerine }\end{array}$ \\
\hline 15 & Sodium chloride & Stomachic, laxative, Antacid & $\mathrm{Na}, \mathrm{Mg}, \mathrm{Cl}, \mathrm{Ca}$ \\
\hline 16 & Black salt & $\begin{array}{c}\text { Antacid, Carminative, stomachic, } \\
\text { laxative, alterative, tonic }\end{array}$ & $\mathrm{Na}$ \\
\hline 17 & Asphalte & Antacid & $\mathrm{Na}, \mathrm{Cl}$ \\
\hline 18 & $\begin{array}{l}\text { Sodiumchloride } \\
\text { impura }\end{array}$ & $\begin{array}{c}\text { Carminative, antacid, stimulant, } \\
\text { stomachic, digestive, refrigerant, } \\
\text { purgative }\end{array}$ & $\mathrm{Na}, \mathrm{Mg}, \mathrm{Ca}$ \\
\hline
\end{tabular}


$\square$ Bitter -3 $\square$ Pungent - $10 \square$ Astringent-2 $\square$ Salt - $4 \quad \square$ Sweet- $2 \square$ Sour-1

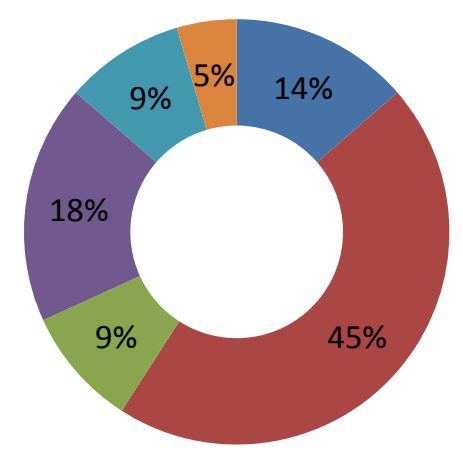

Pungent taste is the highest

form of the ingredients

Fig.3. Total number of ingredients and its taste

$\square$ Hot-14 $\square$ Cold-3 $\square$ Hot \& Cold -1

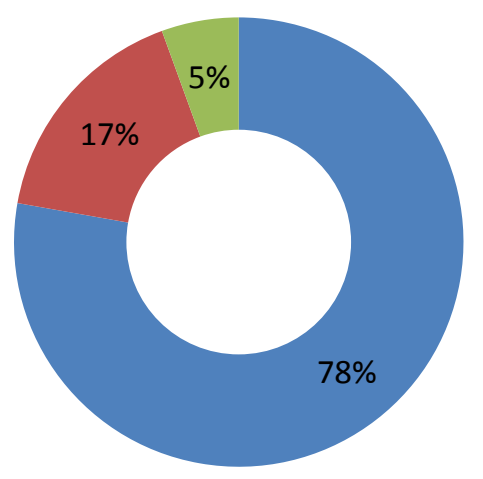

Hot potency is the highest

with fourteen in total number

Fig.4. Total number of ingredients and potency

- Pungent -16 $\quad$ Sweet -2

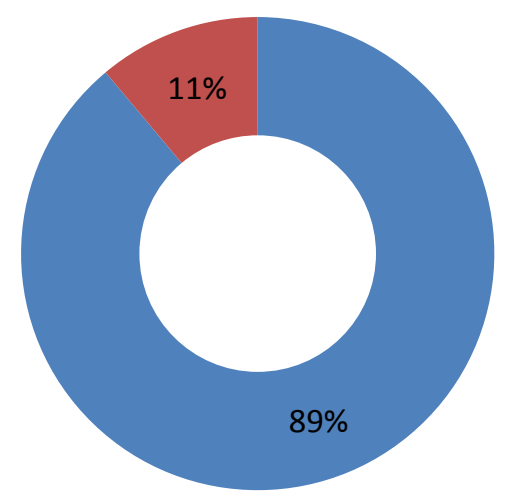

Pungent is the highest

form of the ingredients

Fig.5. Total number of ingredients and its vipakam 
Volume 6, Issue 1, Pages 01-10, January-March 2022

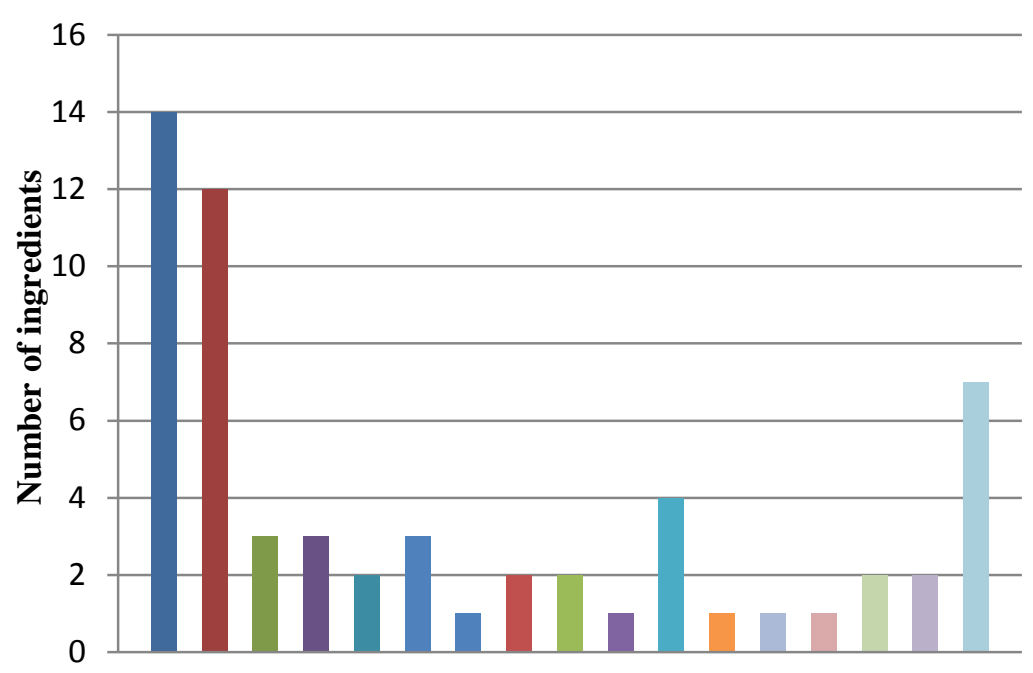

Pharmacological actions

Fig.6. Pharmacological actions of total ingredients
- Carminative-14

- Stomachic-12

- Diuretic-3

- Astringent-3

- Digestive-2

- Tonic-3

- Purgative-1

- Refrigerant-2

Expectorant-2

- Diaphoretic-1

Antacid-4

Antibilious-1

Aromatic-1

Emollient -1

Laxative-2

Alterative-2

Stimulant-7

घolatile oil-8 $\quad$ Essential oil -1 $\quad$ Fixed oil-2 $\quad$ Starch-4 $\square$ Tannin-3 $\square$ Resin-3

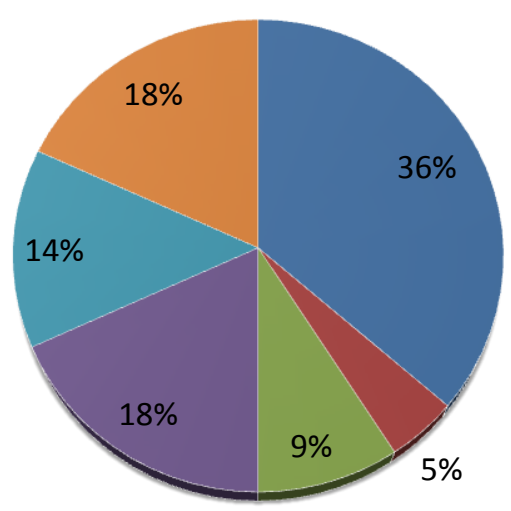

Fig.7. Phytochemicals of plant ingrdients

\section{Conclusion}

This literature review provides useful documented evidence related it's ingredients for ajeeranam in the indigeneous medicine.

\section{Suggestions}

There is need further laboratory study and toxicity study about this drug in future.

\section{Authors' contributions}

This work was carried out in collaboration between both authors. Author JK and YD designed the study, performed the statistical analysis, wrote the protocol and wrote the first draft of the manuscript. Author NRM and NN manage the literature searches and analysis of the study. Both authors read and approved the final manuscript. 


\section{Declarations}

\section{Source of Funding}

This research did not receive any grant from funding agencies in the public, commercial, or not-for-profit sectors.

\section{Competing Interests Statement}

The authors declare no competing financial, professional and personal interests.

\section{Consent for publication}

Authors declare that they consented for the publication of this research work.

\section{Ethical Approval}

Based on Institutional guidelines.

\section{Referances}

[1] K. S. Murukesu Mudaliyar, Materia medica 1 (vegetable kingdom), $1^{\text {st }}$ ed: 1936, Siddha maruthuvam Varrium, Chennai 600106. (pg: 113, 115, 116, 165, 167, 459-462, 760-763, 749-753, 470-472, 514, 517, 463, 390).

[2] KM. Nadkarni, Indian metria medica, (Part 1 \& 2), $1^{\text {st }}$ ed: 1908, Harslha Bhatkal for popular Prakshan Pvt. Ltd., Mumbai. (pg: 98, 99, 110, 108-109).

[3] S.Kanusaamypillai, Kannusamy paramparai vaithiyam, $1^{\text {st }}$ ed: 1953 B.Rathna Nayagar and sons Chennai (pg:82) [4] E.R.Thiyagarajan, (2004) Gunapadam- thathu jeeva vaguppu (Part $2 \& 3$ ) $1^{\text {st }}$ ed:1952, Thiruvalar MLM printers, Kodampakkam, Chennai, 2004 (pg: 60, 369-392).

[5] P. Ramanathan, Siddha Auyrvedha mamaruthuva uthiyohargalana kainool, $1^{\text {st }}$ ed: 1987, Lanka siddha ayurvedha maruthuva kalluuri Jaffna (pg: 55).

[6] K.R. Uththamaraayan, Siddha maruthuvanga surugam, $1^{\text {st }}$ ed: 1967 , India maruththuvam - oomiyopathy thurai Chennai-600106 (pg: 27, 28, 34, 38, 40).

[7] TV. Sampasivam pillai, Tamil english dictionary of medicine, chemistry, botany and allied sciences. Based on Indian Medical science (part 1 and 5), $1^{\text {st }}$ ed:1936, Department of Indian medicine and homeopathy Chennai -600106, 1992 (pg: 553, 554).

[8] D.M.A. Jayaweera, Medicinal plants used in Ceylon (part 1-5), $1^{\text {st }}$ ed: 2006, The national science foundation Sri Lanka, (pg: 217, 218, 233, 209, 139, 205, 67, 117, 73, 83, 207, 137, 243).

[9] What is taxonomy? Convention on bilogical diversity Available: https://www.cbd.int/gti/taxonomy.shtml, June, 2010, Accessed: 20.01.2020.

[10] Raven PH, Evert RF, Eichhorn SE. Biology of plants. $7^{\text {th }}$ ed. (New York: W.H. Freeman). 2005 ; 9.

[11] Plant parts used for medicinal purposes, United states Department of agriculture, Available: https://www.fs. fed.us/wildflowers/ethnobotany/medicinal/parts.shtml, Accessed: 3.2.2020. 
[12] Shukla SS, Saraf S, Fundamental aspect and basic concept of siddha medicines. Systematic Reviews in Pharmacy. 2011; 2(1): 48-54.

[13] Available: https://www.nhp.gov.in/siddha-pharmacology.hmtl.

[14] Available: https://myphoneme.com/nhp portal/nhp/en/siddha?start=95.

[15] Phytochemicals, Available: https://www.phytochemicals.info, Accessed: 18.1.2020.

[16] Available: https://www.ayurtimes.com.

[17] W. Hassan, Journal of nutritional disorders and therapy, antimicrobial activity of Cinnamomum tamala leaves, 2161-0509, www.longdom.org, June 2011, Accessed: 5.1.2020.

[18] www.researchjournal.com.

[19] P. Ramanathan, Mooligai seyal thokuppu (Action of herbs), $1^{\text {st }}$ ed: 2002 Earalai Mahathma Printers, Sri Lanka (pg: 79, 73, 15, 93).

[20] V. Sathiyaseelan, Gunapaadam Metria medica 1, $1^{\text {st }}$ ed: 2008, Harinee Enterprises, Sri Lanka (pg: 230-242).

[21] P. Ramanathan, Siddha Pharmacopoeia, $1^{\text {st }}$ ed: 2000, All Island Services Siddha Ayurvedic Medical officers Union, Jaffna (pg: 35).

[22] S.Sivasanmugarajah, Dict. of Medicinal plants, $1^{\text {st }}$ ed: 2008, Siddha maruththuva valarchchi kalagam (pg: 26). [23] Anaivaari R. Anandan, A Compendium of Siddha Doctrine, $1^{\text {st }}$ ed: 2008, Department of Indian Medicine \& Homoeopathy Chennai-600106 (pg: 22).

[24] Mr \& Mrs. Sathiyaseelan, Siddha Maruththuva thaavara,thaathu, Jeeva moolapporudkalin suththikkirama vilampakam, $1^{\text {st }}$ ed: 2015, Suthesa vaithiya apiviruththi sankam, Kaithady (pg: 226-227).

[25] T. Nadarasan, Paalum athan maruththuva kunankalum, $1^{\text {st }}$ ed: 1984 , Tamilchelvi nilayam 43, Siththiraikkulam vadakkuththeru, Mayilappur, Chennai-600004 (pg: 26).

[26] Available: https://www.rjlbpcs.com.

[27] Available: https://www.planetaayurveda.com.

[28] Available: https://www.medicinenet.com.

[29] Available: https://www.siddham.in.

[30] Available: https://www.en.m.wikipedia.org/wiki/kala-namak.

[31] Cristina carapeto, Silvia Brum and Maria Joao Rocha, Journal of nutrition and Food Science, 2018.

[32] R. Rihan, N. Al-Bakr, R. Shawbakeh, Studying the effect of two corrosion inhibitors in reducing the corrosion rate of 1018 carbon steel petroleum pipelines in sea water, September 2010.

[33] K.N. Kuppusami Muthaliyaar, Siddha Maruththuvam (General), $1^{\text {st }}$ ed: 1936, India maruththuvam - oomiyo pathy thurai Chennai-600106 (pg: 299).

[34] Available: https://www.nischennai.org.

[35] Available: https://www.en.m.wikipedia.org. 